\section{Original Research}

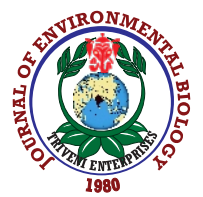

DOI : http://doi.org/10.22438/jeb/41/2(SI)/JEB-07
Journal Home page : www.jeb.co.in ^ E-mail : editor@jeb.co.in Journal of Environmental Biology

p-ISSN: 0254-8704

\title{
Impact of quarries on the Kyrenia mountains (Cyprus) towards human and natural environment
}

\author{
S. İlseven ${ }^{1 *}$ and N. Kaşot ${ }^{2,3}$ \\ ${ }^{1}$ Art and Science Faculty, Near East University Nicosia, Mersin 10, Turkey \\ ${ }^{2}$ Taşkent Nature Park, Cyprus Wildlife Research Institute, Kyrenia, Mersin 10, Turkey \\ ${ }^{3}$ Faculty of Education, Cyprus International University, Nicosia, Mersin 10, Turkey \\ *Corresponding Author Email : silseven66@hotmail.com
}

\section{Abstract}

Aim: This study aims to investigate the impacts of the quarries on the Kyrenia Mountains (Cyprus) in relation to human and natural environment.

Methodology: The quarries located within the territories of North Cyprus were selected for this study. The data was obtained through field surveys, literature review and document analysis. During the field surveys, primarily the affected areas were investigated and photographed. Moreover, face-to-face semi structured interviews were conducted with the local community of Şirinevler and Değirmenlik. In all 20 persons; 10 from each area; were randomly selected and interviewed.

Results: Main environmental problem occur during the blasting activities at quarries. These include ground tremors, air cannons, rock throwing and dust. These blasts can damage the surrounding buildings as well as create psychological problems for human population living around the area. These problems include fear, concern and stress on the residents of surrounding neighbourhood. The workers can also suffer from dizziness, attention deficiency, blackout and temporary issues with regard to the high temperatures due to such blasts. As a result of blasts, dust, chemical leakage, hazardous fumes, heavy metals and radiation-containing substances cause permanent occupational diseases. Big trucks and lorries owned by quarries or visiting quarries for excavation, damage roads as well.

Interpretation: The lack of legislation with regard to the improvement of quarries should be adopted as soon as possible and the horrible structural deformation eliminated by applying bench blasting system. Issuing of permits for new quarries should be stopped.

Key words: Environmental impact, Kyrenia Mountains, North Cyprus, Quarries
Quarries impact natural and social environment in Girne Range

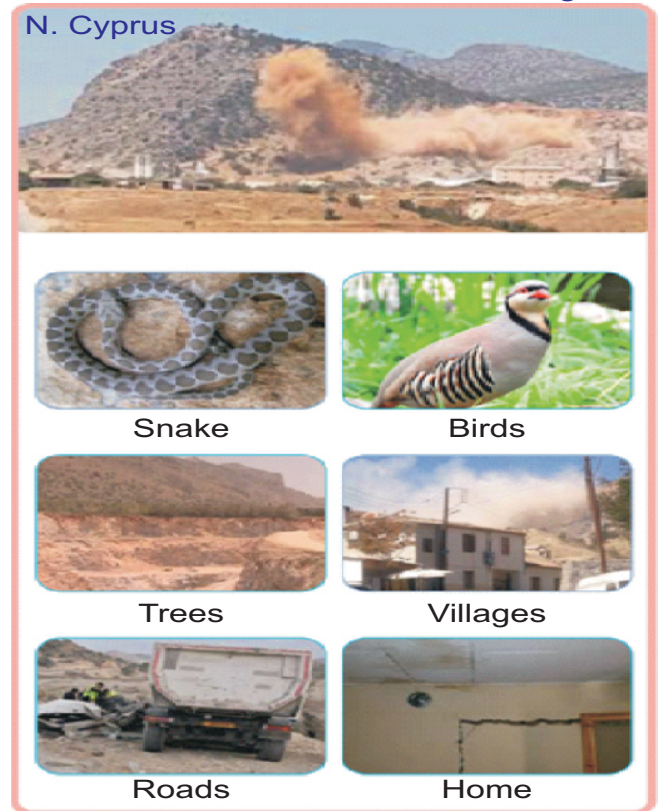

How to cite : Ilseven, S. and N. Kaşot: Impact of quarries on the Kyrenia mountains (Cyprus) towards human and natural environment. J. Environ. Biol., 41, 323-327 (2020). 


\section{Introduction}

Quarrying is the process of extracting raw materials from the earth. This has been going on for thousands of years for industrial and construction purposes (Sandecki, 1989; Kondolf, 1994). There are different types of quarries. For each quarry, there is a specific technique or way to extract the material, some of them randomly using old technique by explosion and the new way is using technology like laser, which is more preferable technique. Aggregate quarries refer to sand and gravel, which naturally come from cobbles and boulders frictions in river channels due the water flow when they sculpt the land surface on their way (Dávid, 2010; Kondolf, 1997). Stone quarries have visual impact on the environment which occursduring and after production phase of the quarries by creating deep holes. This action ruins the topographic structure of the area. The damage that occurs is not repairable after the excavation, beside these activities affect growth of plants, ground water and air (Çelik, Sarışık and Gürcan, 2003).

Urbanization has a major role on the demand for an extensive use of natural resources. It includes constricting more buildings for building larger cities but leading to severe environmental issues. According to Morel et al. (2001) "Throughout the world, the building industry is responsible for high levels of pollution because of the energy consumed during extraction, processing and transportation of raw materials". Kivinen (2017) stated that demand for opening more excavation sites followed by the activities either during or after the process of extracting the material, for each site require special rehabilitation, therefore, important point is to think about the sustainable development, environmental concern must be taken into consideration during the excavating process. According to Ilseven (2017), the changes that occur on land surface due to mining activities can affect both quality and quantity of water in aquifers, as these changes lead to modification of recharge rate to groundwater, and result in inclination of water path from its original course, and all these changes may increase or decrease recharge rate to groundwater. Worrall and Kolpin (2004) have stated that shorter flow path raises the vulnerabilities of water to contamination. Thornton and Whalen (2009) reported that sand and gravel mining in Peckenham has changed both the quantity as well as quality of water. They found that the aquifer was susceptible to contamination by chloride and nitrate, which cannot be directly due to mining activities.

The first quarry on the Kyrenia Mountains was opened in Değirmenlik to provide supply for the construction of NicosiaFamagusta road, which was followed by the quarry in the north of Alemdağ for the construction of Morphou-Nicosia highway and despite the completion of both roads, the quarries remained open (Alkaravlı, 2007). It is stated that the quarries on the Kyrenia Mountains expanded to an area of $651000 \mathrm{~m}^{2}$. Out of 36 operating companies, 16 were for crushing stone sand, 11 for float stone, 6 for cut stone, 2 for gypsum and 1 for river sand and gravel
(Department of Geology and Mining, 2017). The surface pit industry of the quarries in Cyprus creates major environmental impacts. The open quarries directly target the top part of earth's crust and cause geomorphological changes which are irremediable in short time. The environmental organizations consider such scenes as disasters of century and settlers close to the quarries react against these situations. The problems arising from the quarries are at the maximum level in the residential areas like; Akçiçek, Alemdağ and few others lying at close distance. During the drilling and detonation processes in the quarries, a number of impacts arise such as scattered stones, air cannon and ground vibration as well as environmental impact like dust, contamination in the ground water resources, displacement and exposure, visual pollution and loss of land during the size reduction processes. This study has identified that fatal accidents occur on the Kyrenia Mountains and Değirmenlik road. Their number has increased and lorries- trucks carrying excavations from the quarries are mainly responsible for these accidents (IIseven and Kaşot, 2017). In view of the above, this study aimed investigate the impacts of quarries on the Kyrenia Mountain (Cyprus) on human and natural environment.

\section{Materials and Methods}

The quarries located within the territories of North Cyprus were selected for this study. Data was collected through field surveys, literature review and document analysis. During field surveys, the affected areas were primarily investigated. The total number of traffic accidents caused by the lorries and trucks working for the quarries during 2006-2017 were recorded and are presented in Table 1. In addition, face-to-face semi-structured interviews were conducted with the local community from Şirinevler and Değirmenlik. Semi-structured interviews are nonstandardized and are frequently used in qualitative analysis. The interviewer does not do the research to test a specific hypothesis. The researcher has a list of key themes, issues and questions to be covered. In this type of interview the order of the questions can be changed depending on the direction of the interview (David and Sutton, 2004). A total number of 20 people- 10 from each areawere interviewed randomly. During the interviews, the inhabitants were asked whether quarries have any harm on their health, environment, psychology and property. They were also asked to answer whether quarries create any employment opportunity for them. The semi-structured interviews (Bargali et al., 2007,2009; Pandey et al., 20011, Parihaar et al., 2015a, b) were analysed through content analyses and tabulated accordingly.

\section{Results and Discussion}

Geological and Geomorphological Structure of Kyrenia Mountains: Kyrenia Mountains run parallel with the northern coasts of Cyprus as a single line of $160 \mathrm{~km}$. One of their important features is that they run without any interruptions in the direction east to west. Such mountains covering a narrow area end with 
sudden lowering, but look majestic from a distance (Illseven, 2017). The exhumation area of these mountains is the northern part of Cyprus. The area forms the southern part of Taurus-Persia mountain formation zone within the Alpian-Himalaya mountain belt. Allochthonous solid and recrystallized limestone, dolomite and marble are the main surface forms of this area. The age of allochthonous rocks vary from Permian-Carboniferous to Upper Cretaceous (nearly 350-135 million years ago). Such rocks are followed by stratigraphic younger and residual (autochthonous) sedimentary rocks. The age of such autochthonous rocks vary between Upper Cretaceous and Miocene (nearly 67-15 million years ago) and the allochthonous units are mounted on these rocks towards south (ilseven et al. 2014).

Limestone is the main structure of Kyrenia Mountains formed as a result of Alpine Orogeny and folding in Tethys Sea. The huge masses of limestone are formed based on the subductions ranging from north to south as a result of subduction of African plate beneath Anatolian plate (illseven and Baştaş, 2018). They have a hard structure due to crystallised features. The limestone on these mountains are categorised under four main formations as Kantara, Dikmen, Kaynakköy and Hilarion. The crushed-stone production at quarries is mainly performed at Hilarion Formation. The limestone, which is observed in light to dark as grey, black or white in the form of massif, hard, breccia and partly crushed zones, comprise of marble and dolomite (Alkaravli, 2007). It is not possible to give the exact thickness due to the faulting and subduction formed by the tectonic evolution of Kyrenia Mountains. They constitute a thickness from 5-6 meters to 600-700 meters Quarry area. Such formations are aged from Jurassic-Middle Cretaceous, are located at Upper Dikmen region, and have $250 \mathrm{~m}$ thickness. Their colors range from light to dark in bluish black and white (illseven et al., 2014).

Geographical distribution of quarries on Kyrenia Mountains: The quarries in the "Turkish Republic of Northern Cyprus" (TRNC) are distributed in an area of $651000 \mathrm{~m}^{2}$. Out of 36 companies, 16 operate for crushed stone sand, 11 for float stone, 6 for cut stone, 2 for gypsum and 1 for river sand and gravel (Fig. 3) Up to 1990, the gravel and sand need of North Cyprus was supplied from the area on the coastline of KumköyGaziveren and also sand-gravel was supplied from streambeds. The first principle of material from the northern slope of mountains. The quarry pits were opened and operated prior to 1974 Peace Operation such as Kyrenia Strait, Güngörköy, Değirmenlik and Büyükkonuk. Their operations were increased with the growth of production need.

Impacts of quarries on environment and humans in the area : Major environmental problem is the blasting activities at quarries. There are ground tremors, air cannon, rock throwing and dust. Such blasts can cause damage to the surrounding buildings, but also create psychological problems like fear, concern, stress on the residents of neighborhood. The workers can suffer from dizziness and hearing deficiency from the blasts, but blackout and temporary issues with regard to high temperatures due to such blasts can also be effective. As a result of blasts, dust, chemical leakage, hazardous fumes, heavy metals and radiationcontaining substances cause permanent occupational health defects. During field study, we recorded that the inhabitants in both Şirinevler and Değirmenlik complained about the dust coming from the quarries. The second most complaint was the damage caused by the tremors in the dwellings due to the blasts at the quarries. During the blasts, the windows of many houses in Değirmenlik break and deep cracks occur on the walls of some houses following the underground tremors caused by the blasts. During our interviews in Şirinevler, locals living close to the quarry mainly complained about the deep cracks of house walls due to the blasts as well as dust in their houses from the trucks using the surrounding roads. The villagers complained that biodiversity of the area is highly damaged. Indeed impact of quarries in the area on the natural vegetation is significantly high because, hundreds of bushes and trees are cut down as the dust from quarries leads to the death of plant life. The pasture vegetation areas too have disappeared at places where excavations from quarries have been and are carried out. The damage of vegetation means a breakdown in the nutrition chain.

Big trucks and lorries owned by quarries or visiting quarries for excavation, damage roads as well. During summers, ditches appear on soft asphalt roads due to these heavy trucks. In addition to ditches and cracks, sand and gravel falling from trucks all along the road these travel also pose danger for human health. Hence, the mountain road from Kyrenia to Ercan airport is prove to fatal accidents. During four accidents, which took place on this road since 2007, 13 people have lost their lives. Approximately, 10 persons lost their lives due to the accidents with the involvement of trucks carrying excavation from quarries (Bulletin General Directorate of Police Dept., 2006). Within the framework of TRNC traffic accidents, Table 1 presents data on the accidents, which took place involving trucks and lorries carrying excavations from the quarries. Considering the total traffic accidents in TRNC during the last decade, 18 percent show involvement of trucks and lorries, which reflects the significance of topic. High amount of explosives are used to extract stones from the quarry face that were left at high levels over time at the quarries particularly close to Değirmenlik and Şirinevler. Such explosives cause major tremors in the area, creating a significant damage on the dwellings.

The quarries have also negative impact on the groundwater by changing the physical as well as chemical characteristics together with the temperature of existing surface and groundwater resources. With the interruption of water exchange between the ground water layers, the direction and velocity of water flow is disrupted following non-recovery of water flow. Particularly, the Değirmenlik community have responded that the blasts as a reason for drying of Değirmenlik and Başpınar. Further, the blasts at quarries pose great damage on the 
Table 1 : Accidents involving trucks and lorries carrying excavations from the quarries

\begin{tabular}{llll}
\hline Year & No. of traffic accidents & Truck and lorry & Other vehicles \\
\hline 2006 & 43 & 18 & 25 \\
2007 & 39 & 4 & 35 \\
2008 & 37 & 10 & 27 \\
2009 & 38 & 5 & 33 \\
2010 & 37 & 4 & 33 \\
2011 & 37 & 6 & 31 \\
2012 & 22 & 1 & 21 \\
2013 & 44 & 5 & 39 \\
2014 & 23 & 1 & 22 \\
2015 & 25 & 6 & 19 \\
2016 & 34 & 6 & 28 \\
Until April 2017 & 11 & 3 & 8 \\
Total & 390 & 69 & 321 \\
\hline
\end{tabular}

Table 2 : Content analysis of interviews from two settlements.

\begin{tabular}{llll}
\hline Question & Theme & Frequency & Percentage $(\%)$ \\
\hline Do you think that quarries affect your health? & Yes & 10 & 100 \\
Do you think that quarries damage the environment? & Yes & 10 & 100 \\
Doyou think that quarries have an impact on your psychology? & Yes & 10 & 100 \\
Doyou think that quarries damage your property? & Yes & 10 & 100 \\
Doyou think that quarries open job opportunities for you? & No & 10 & 100 \\
\hline
\end{tabular}

groundwater resources in the surrounding area as well as Başpınar.

Quarries have also deteriorated the geo-morphological structure of the area. They have damaged the Beşparmak Hill, which is considered as the identity of country as one of the important and characteristic part of Kyrenia Mountains; is irrevocable. The fauna too is affected in the area close to quarries due to habitat damage. Many species have already disappeared. Especially, the bird population in the surrounding areas of quarries has significantly decreased (Kaşot, 2017; Kuyucu, 2013). S i n ce quarries are adjacent to the residential areas, the dusts in air seriously threaten human health. People have difficulties in breathing and people with respiratory problems cannot open their doors and windows and walk around the streets.

Interview findings : A total number of 20 inhabitants from two different settlements, 10 from each area, were interviewed at random within the scope of this study. The content analysis with regard to the questions is presented in Table 2. The table shows that all participants indicated that quarries damage their health, psychology, property and environment. All mentioned that quarries do not create job opportunities. They answered that people have a negative perception about quarries. It can be stated that the local communities are not happy with quarries and do not support their existence. The Chapter 270 Mines and Quarries Regulation Law, which regulates quarries and mine processing since it entered into force in 1960, should be updated. With the aim of supervision and controls on the quarries in TRNC, "The Secondary Legislation on the Regulation and Supervision of
Quarries" has entered into force upon its publication in the Official Gazette on 24 November 2015. Although this regulation is an important development regarding the quarries, the general inspections at quarries have not yet commenced as of May 2016. The lack of legislation with regard to the improvement of quarries should be adopted as soon as possible and horrifying structural deformation eliminated by converting to bench blasting system. In this system, afforestation should be performed where necessary, artificial soil, on the benches, which would prevent noise pollution, and the flora and fauna in the area, should be improved accordingly. Çeliket al., (2003) stated that marble and stone quarries negatively affect the general structure of natural environment as well as air, ground and surface waters. Our study fully goes in conformity with these findings. Ditch and masonry hills, which deteriorate the topography of land, too result from the quarry activities. They create visual pollution followed by psychological reactions. Our interview results fully support the early findings in this connection.

There is no need to give permits for new quarries. The highest amount of excavations needed in TRNC is around 18.000 tons; however, the capacity of operating quarries has more than 30.000-ton capacity. In accordance with the need analysis, opening new quarries is not suitable, even merging some quarries would be a better decision. The inspections should be more effective and the Ministry of Tourism and Environment, particularly the Environmental Protection Department, should impose more deterrent penalties against the quarries that do not operate in compliance with the applicable legislation. Upon the completion of excavation at the quarries, the excavated rocks, 
management method, socio-cultural characteristics of surrounding areas, social needs and relations with the type of use in the surrounding areas should be taken into consideration as the most significant aspect in the determination of the future use of such areas (Topay et al., 2007). The loopholes in the application of local legislation should be identified in parallel with the opinions of related professionals; most appropriate solutions should be proposed and guaranteed under the related laws, which would make up a significant deficiency in terms of sustainability of resources. In the years following the functioning of quarries, the residential and industrial developments have increased in their surrounding rural areas. With the assumption that the number of such developments would increase, the quarries should be merged; a major number of quarries should be closed and the quarries located in remote areas, i.e., far from settlements, should be granted permits for operation.

The rehabilitation activities have major impact on the elimination or minimisation of environmental problems caused by quarries. Biological reclamation and vegetation have a significant effect on the recovery of destroyed areas. The vegetation of lands with appropriate plant species and accurate vegetation techniques in consideration with over arid spring and summer seasons of TRNC should be performed, and correspondingly the ecological, economic and aesthetic assets in the area reformed and recovered. Considering the general characteristics of existing quarries in TRNC, a significant number do not work in accordance with international production standards by using gallery blasting method. This has a negative impact in terms of safety and environment. Such circumstances caused damage on the natural resources, pollute our air and water, distort the ecological balance and produce negative impact on human health and life (Karaman and Kılıç, 2012). The results of this study clearly reflects the same outcomes. Quarries in TRNC have a negative impact both on natural environment and on human health. Especially, the figures of traffic accidents reveal the significance of situation. Immediate solutions should be introduced in terms of environment and humans.

\section{References}

Alkaravlı. M.: K.K.T.C'de Madencilikve Çevre, (Mining and Environment in TRNC) Department of Geology and Mining Publications, Nicosia (2007).

Bargali, S.S., S.P. Singh, S.K. Shrivastava and S.S. Kolhe: Forestry plantations on rice bunds: Farmers' perceptions and technology adoption. Int. Rice Res. Notes, 32, 40-41 (2007).

Bargali, S.S., K. Pandey, L. Singh and S.K. Shrivastava: Participation of rural women in rice based agroecosystem. Int. Rice Res. Notes, 33, 1-2 (2009).

Çelik, M.Y., A. Sarışık and S. Gürcan: Mermerve Taş Ocaklarının Çevreye Olan Görsel Etkileri, (Environmental Impacts of Marble and Stone Quarries, $4^{\text {th }}$ Marble Symposium, 18-19 December, Afyon) Proceedings book. 4th Marble Symposium in Turkey-19
Dec, Afyon, pp. 463-474 (2003)

David, L.: Quarrying: An Anthropogenic Geomorphological Approach. Acta Montanistica Slovaca Rocník 13, císlo 1, Springer, Dordrecht, pp. 66-74 (2008).

David, M. and C.D. Sutton: Social Research the Basics. London: SAGE Publications (2004).

Department of Geology and Mining of TRNC: Statistical data (2017).

Illseven, S.: Analysis of Garrigue and Maquis communities on the island of Cyprus and comparison with Calabrian pine communities in terms of ecological characteristics. J. Env. Bio., 38, 955-960 (2017).

Illseven, S., G. Hıdırer and A. Tümer: Kıbrıs Coğrafyası, (Geography of Cyprus, Cyprus) Turkish Education Foundation Publication, Nicosia (2014).

Illseven, S. and M. Baştaş: The place of eucalyptus within the vegetation of Mesaoria Plain (Cyprus) and the views of vegetation geography lecturers. EURASIA J. Mathem., Sci. Tec. Educ., 14, 3381-338 (2018).

Karaman, B. and Ö. Kılıç: Açık ocak madencliği sırasında bozulan sahaların yeniden düzenlenmesive kktc'de bazı uygulamalar, (Reconstruction of the areas damaged during open pit mining and some practices in the TRNC). J. Sci. Engin., 27, 178-187 (2012).

Kaşot, N.: Çevreeğitimi.(Environmental education) Ankara: Eğiten Kitappress (2017).

Kivinen, S.: Sustainable post-mining land use, are closed metal mines abandoned or re-used space? Sustainability, 9, 1-18 (2017).

Kondolf, G.M.: Environmental planning in regulation and management of instream gravel mining in California. Landscape Urban Plan, 9, 185-199 (1994).

Kondolf, G.M.: Profile: hungary water: Effects of dams and gravel mining on river channels. Environ. Manag., 21, 533-551 (1997).

Kuzey Kıbrıs Türk Cumhuriyeti, Polis Genel Müdürlüğü Bülteni: (Bulletin of General Directorate of Police of Turkish Republic of Northern Cyprus) (2016).

Morel, J.C., A. Mesbah, M. Oggero and P. Walker: Building houses with local materials: means to drastically reduce the environmental impact of construction. Build. Enviro., 36, 1119-1126 (2001).

Pandey, K., S.S. Bargali and S.S. Kolhe: Adoption of technology by rural women in rice based agroecosystem. Int. Rice Res. Notes, 36, 1-4 (2011).

Parihaar, R.S., K. Bargali and S.S. Bargali: Diversity and uses of ethnomedicinal plants associated with traditional agroforestry systems in Kumaun Himalaya. Indian J. Agric. Sci., 84, 1470-1476 (2011).

Parihaar, R.S., K. Bargali and S.S. Bargali: Status of an indigenous agroforestry system: A case study in Kumaun Himalaya, India. Indian J. Agric. Sci., 85, 442-447 (2015).

Peckenham, J. M., T. Thornton and B. Whalen: Sand and gravel mining: Effects on ground water resources in Hancock county, Maine, USA. Environ. Geol., 6, 1103 (2009).

Sandecki, M.: Aggregate mining in river systems.Califgeol, 2, 88-94 (1989).

Topay,M., Ş.S. Aydın, and N.Koçan: Taşocaklarının peysaja etkileri ve yeniden kullanımalarına yönelik çözüm önerileri, (Effects of quarries on landscape and solutions to the reusage of them). Suleyman Demirel University. J. For. Fac., 2, 134-14 (2007).

Worrall, F. and D.W. Kolpin: Aquifer vulnerability to pesticide pollution combining soil, land-use and aquifer properties with molecular descriptors. J. Hydrol., 293, 191-204 (2004). 